\section{NEWXYSBKHOOL}

Faculty Scholarship digitalcommons.nyls.edu

Articles \& Chapters

$3-1-2003$

\title{
The Environment and the World Trade Organization
}

Sydney M. Cone III.

New York Law School, sydney.cone@nyls.edu

Follow this and additional works at: http://digitalcommons.nyls.edu/fac_articles_chapters

\section{Recommended Citation}

46 N.Y.L. Sch. L. Rev. 3-4

This Article is brought to you for free and open access by the Faculty Scholarship at DigitalCommons@NYLS. It has been accepted for inclusion in Articles \& Chapters by an authorized administrator of DigitalCommons@NYLS. 


\title{
THE ENVIRONMENT AND THE WORLD TRADE ORGANIZATION
}

\author{
Sydney M. Cone, III*
}

\section{INTRODUCTION}

The meeting of the members of the World Trade Organization ("WTO") in Seattle in late 1999 was seriously disrupted by street demonstrations which turned the meeting into a disaster. ${ }^{1}$ Prominent among the demonstrators were people purporting to be from environmental non-governmental organizations ("NGOs"). A number of these protestors costumed as sea turtles, were pictured, thus clad, in newspapers and magazines, ${ }^{2}$ and received considerable attention on television as well as from the Seattle police department. Dissemination by the media of images of people masquerading as sea turtles was expected to, and did, seriously taint the image of the WTO, causing it to be seen as the headquarters of forces hostile to the environment.

The purpose of this article is not to defame environmental NGOs. Indeed, so far as the author knows, they did nothing more in respect of the Seattle fiasco than to countenance, or to subsequently refrain from disavowing the antics of protestors cavorting as anthropoid sea turtles. Rather, the purpose of this article is to argue that the WTO was badly used by the Seattle demonstrators, that its role as regards sea turtles has been quite the opposite of what those demonstrators were suggesting, and that environmental NGOs should exert informed efforts on behalf of the WTO, because it is the very type of multilateral body that they should support if they expect to succeed in protecting the world's environment.

* C.V. Starr Professor of Law and Director of the Center for International Law at New York Law School, and Of Counsel, Cleary, Gottlieb, Steen \& Hamilton. Haverford, B.A. 1962; Yale, LL.B. 1959. Professor Carlin Meyer of New York Law School having prompted this article, it is dedicated to her.

1. See The WTO After Seattle 3 (Jeffrey J. Schott ed., Institute for International Economics 2000).

2. See, e.g., Michael M. Weinstein \& Steve Charnovitz, The Greening of the WTO, Foreign Affairs, Nov.-Dec. 2001, photograph at 149. 


\begin{tabular}{|c|c|c|c|}
\hline 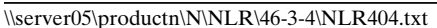 & unknown & Seq: 2 & 20-FEB-03 \\
\hline
\end{tabular}

\section{The WTO And Sea Turtles}

First, a bit of background seems in order about the interaction between the WTO and sea turtles as found in nature (as distinguished from the streets of Seattle). Various species of sea turtles face extinction by drowning in the nets of vessels trawling for shrimp. In an attempt to save them from extinction, the United States Congress passed a law requiring U.S. shrimp vessels to use nets equipped with devices that exclude sea turtles, and banning U.S. imports of shrimp from other countries unless their vessels use nets that are likewise equipped. ${ }^{3}$ The U.S. State Department, not eager to enter into negotiations with certain Asian countries, namely, India, Pakistan, Thailand, and Malaysia, enforced the law, first, by treating the Asian countries as not covered by the law, and, later, after U.S. courts had held the law to apply to the Asian countries, by simply banning imports of shrimp from those countries. In contrast, the State Department entered into negotiations with relevant countries in the Western Hemisphere that resulted in those countries equipping their shrimp-trawling vessels with nets meeting U.S. standards. A key result of the negotiations was U.S. assistance to Latin American countries seeking to comply with U.S. standards.

The four Asian countries complained to the WTO. It held that the United States had improperly discriminated against the Asian countries, and in effect called for the parties to settle the matter through negotiation. Environmental NGOs in the United States were unhappy with this disposition of the case by the WTO. Their fear was that the WTO had opened the door for shrimp trawling by the Asian countries that would put species of sea turtles in peril. The Seattle demonstrators took it from there.

The matter was more complicated than a caricature of the WTO as an exterminator of endangered species. The WTO did not have jurisdiction over the State Department. Certain NGOs sued the State Department in U.S. courts having such jurisdiction, and those courts held that, by not applying the relevant U.S. law to the four Asian countries, the Department had failed to carry out the intent of Congress. It

3. This background information is based in part on Sydney M. Cone, III, The Appellate Body, the Protection of Sea Turtles and the Technique of "Completing the Analysis," 33(2) J. of World Trade 51 (1999), and sources cited therein. See also Jagdish Bhagwati, Coping with Antiglobalization, Foreign Affairs, Jan.-Feb. 2002, at 3-4. See generally Symposium, The Greening of the World Trade Organization?, 21 N.Y.L. ScH. J. INT'L \& Comp. L. 147 (2002). 
was the U.S. courts, not the WTO that brought the trade issue to a head with respect to the four Asian countries. The U.S. courts instructed the State Department that under U.S. law shrimp could not be imported if caught in nets that drown sea turtles. When the United States then banned Asian-source shrimp and the four Asian countries complained to the WTO, the role of the WTO was limited to saying that the United States, under relevant multilateral agreements governing trade, could not legally treat the Asian countries less favorably than it treated countries in the Western Hemisphere. Thus, the United States found itself in the position of being statutorily compelled to ban shrimp from Asia if the vessels trawling for the shrimp drowned sea turtles in the process, and, notwithstanding the reluctance of the State Department to open negotiations with countries that might prove difficult, of being required to grant those countries treatment no less favorable than the treatment it granted to other countries. In order to grant such treatment, the Department would have to try to reach an agreement with those countries similar to the U.S. agreement with Western Hemisphere countries, that is, an agreement under which the countries (1) agreed that their vessels would use shrimp-trawling nets that do not drown sea turtles, and (2) could be expected to seek U.S. assistance similar to that accorded countries in the Western Hemisphere.

At the time of the Seattle demonstrations, the United States was actually refusing to import shrimp from the four Asian countries, and thus was carrying out rather vigorous measures in response to the plight of sea turtles. What the WTO had done was remind the United States that it had an obligation under the relevant WTO agreements to observe multilateral standards, and not merely to proceed unilaterally to exclude Asian-source shrimp from the U.S. market. The United States was thus under an obligation, set forth in international treaties relating to the WTO, and in a WTO decision based thereon, to try to reach an agreement with the four Asian countries similar to the agreement between the United States and certain other Western Hemisphere countries, the result of which would be to admit shrimp into the U.S. market only if the nets used to catch the shrimp did not drown sea turtles. The Seattle demonstrations (to the extent that the demonstrators could be said to have been informed about and to have reflected on the matter) thus seemed to prejudge the ultimate outcome of the WTO decision calling on the United States to replace unilateralism with "serious" negotiations. By reaching a decision calling 
for "serious" negotiations between the parties, the WTO had taken the matter as far as its mandate and powers permitted.

For the reasons just mentioned, the ultimate outcome depended on negotiations between the United States and the four Asian countries. Unless and until the negotiations were successfully concluded, the Asian countries were free to trawl for shrimp in a fashion that drowned sea turtles, the only inhibition being the commercially potent one that the shrimp could not be sold in the U.S. market because, meanwhile, the United States was refusing to import shrimp from those countries. The contextually unhelpful Seattle demonstrations to one side, the best result that environmentalists could hope for was that the United States would reach an agreement pursuant to which the four Asian countries, in trawling for shrimp, would cease drowning sea turtles. The time consumed in arranging for and carrying out the negotiations was a time of continued endangerment of certain species of sea turtle, but the environmental NGOs concerned with their plight were not in a position to do more than urge the parties to negotiate. The NGOs were, in this respect, very much in the same position as the WTO.

To recapitulate: The incentive for the four Asian countries to negotiate was access to the U.S. market for shrimp. Both the WTO, through its decision, and the NGOs, through litigation against the State Department, had acted to bring the matter to the point where negotiation was the next step.

Negotiations were in fact undertaken, and three of the four countries, India, Pakistan, and Thailand, reached an agreement with the United States. Those three countries agreed to adopt measures whereby their shrimping fleets would use devices designed to avoid the drowning of sea turtles, and the United States agreed to withdraw its prohibition on importing shrimp from those three countries.

Malaysia, however, took the position that, once it was in the process of negotiating with the United States, the United States should drop its ban on the importation of shrimp from Malaysia. The United States was of the view that, as with India, Pakistan, and Thailand, it was negotiating in good faith and was entitled to maintain its ban until the negotiations resulted in an agreement. This U.S.-Malaysian impasse resulted in another proceeding under the dispute-settlement rules of the WTO.

This proceeding was brought by Malaysia against the United States. A WTO panel ruled against Malaysia in June 2001. Malaysia 
appealed this ruling to the WTO's Appellate Body, which in turn ruled against Malaysia in October 2001. ${ }^{4}$ On the basis of the panel report and that of the Appellate Body, it seems fair to say that, in the guise of raising procedural points under the relevant WTO agreements and rules, Malaysia was simply relitigating the WTO decision calling for negotiations between Malaysia and the United States. Moreover, from the perspective of the NGOs, the WTO rulings against Malaysia would seem to be rather firmly pro-environment, for they had the effect of indicating to Malaysia that it could be legitimately denied access to the U.S. market so long as its shrimping fleet continued to drown sea turtles.

\section{The NGOs and Multilateralism}

As has been seen, the matter of shrimp and sea turtles was the subject of litigation both domestically in the United States and multilaterally under the auspices of the WTO. In the overall context of that litigation, both the WTO and the NGOs took essentially the same position, namely, that the related questions of access to the U.S. market and of safeguarding sea turtles from drowning by the shrimping fleets of the four Asian countries should be resolved through negotiations between the United States and those countries. One could thus conclude that environmental demonstrations against the WTO in the name of protecting sea turtles made no sense because (1) the NGOs and the WTO had adopted quite congruent positions and (2) the views of the environmentalists had prevailed. Proving the soundness of this conclusion would be but a minor achievement, however, since legal scholars who actually read the cases can be presumed to have an intellectual advantage over self-promoters who, certain of their grasp of the failures of globalization and rightly sensing the relative pleasures of taking to the streets as against slogging through endless pages of legal pleadings and juridical opinions, prefer the former to the latter.

The larger point is not that the street demonstrators were somewhat lacking in erudition. The larger point is that the NGOs themselves seem oblivious to the extent to which the cause of protecting the global environment is but one piece in the development of effective multilateral policies and institutions. The NGOs do not seem to un-

4. WTO Report of the Appellate Body, United States-Import Prohibition of Certain Shrimp and Shrimp Products: Recourse to Article 21.5 of the DSU by Malaysia, AB-2001-4, WT/ DS58/AB/RW at 49-51 (Oct. 22, 2001). Much of the background summarized herein is set out in this Report. 
derstand the extent to which WTO-bashing is harmful to that development and, therefore, to the very objectives espoused by the NGOs.

Even when it is viewed in isolation, the shrimp/sea turtle case illustrates the futility of WTO-bashing. The extinction of the WTO would not advance the cause of saving sea turtles from extinction. True, individual governments would then be free to ban or allow the importation of shrimp unfettered by rules requiring that a nation's trade policies be even-handed from a multilateral perspective. When, however, a country unilaterally bans shrimp imports from one nation but not from another, the ban in and of itself does nothing to save sea turtles caught in the nets of the vessels of the disfavored country. Sea turtles, if not destroyed by (for example) shrimp trawlers, swim great oceanic distances in seeming ignorance of national boundaries. Saving them from extinction perforce calls for inter-governmental co-operation. Unlike the U.S. State Department, the NGOs were motivated by global environmental objectives, and perceived that those objectives would not be well-served if inter-governmental co-operation were confined to the Western Hemisphere. The United States, by acting unilaterally to exclude Asian-source shrimp from the U.S. market, did not prevent Asian shrimp trawlers from drowning sea turtles in their nets. Inter-governmental co-operation proved necessary in order to further that objective.

Important as it may be when viewed alone, the cause of saving sea turtles from extinction takes on far more importance when viewed as a proxy for saving the global environment. A global problem would seem to call for a global solution, a principle which, to their credit, the NGOs champion and in the service of which they devote no little energy. But how might that energy be channeled in a direction and manner susceptible of achieving a global solution? One possible answer lies not in bashing the WTO for its effectiveness in the area of international trade, but in analyzing why the WTO is effective, and whether it might not serve as a model for advocates of an effective global approach in dealing with environmental concerns.

An attempt will be made below to supply that analysis. First, however, three comments will be made about globalization, a topic which seems to arise automatically in any discussion of the role of the WTO.

1. Globalization is considered to be a threat to (a) countries exporting capital that, if invested at home, would provide employment for home-country workers, (b) countries receiving direct foreign investment from abroad in a form that exploits host-country labor or has 
other adverse effects in the host country, and (c) countries importing goods and services from abroad which take markets away from local producers and suppliers. The first category involves questions of capital controls. The second category points up the relative ineffectiveness of the International Labor Organization. The first and second categories underscore the failure of negotiations to achieve a multilateral agreement on investment. Only the third category relates in a significant way to the mandate of the WTO, which (briefly put) is to enforce rules developed by WTO members to remove barriers to free trade. ${ }^{5}$

2. These rules go back over fifty years, to the signing of the original General Agreement on Tariffs and Trade ("GATT"), ${ }^{6}$ at a time when a number of multilateral agreements and institutions were adopted or created to provide for a global approach to problems faced by countries emerging from World War II. One of these problems took the form of high protectionist barriers to trade, barriers whose creation or exacerbation in the 1930s contributed to the international friction that degenerated into World War II. The mandate of the WTO incorporates the jurisprudence developed between the signing of the original GATT and the creation of the WTO and WTO disputesettlement is very much grounded in that jurisprudence. ${ }^{7}$ Thus, the role of the WTO has an historic basis that antedates the current debate over (and current usage of the term) globalization.

3. Notwithstanding the often polemical nature of the debate, globalization has its undeniably non-polemical characteristics, in the sense that (to take two examples) both trade and the environment are undeniably global in nature. Merely to describe them is to describe global phenomena. As a result, to say that an NGO or the WTO is concerned with, or seeks to foster, globalization is simply to initiate the analysis.

5. The WTO is also charged with responsibility under the Agreement on Trade Related Aspects of Intellectual Property ("TRIPS"), and was involved in the process whereby companies holding patents on pharmaceutical products used for AIDS agreed to reduce prices charged in developing countries.

6. As originally conceived, the GATT was to be implemented by an International Trade Organization. The U.S. Congress blocked the creation of this multilateral organization. The GATT then became both a multilateral institution, based in Geneva, Switzerland, as well as a multilateral agreement. The WTO came into being on January 1, 1995 , to implement a number of multilateral agreements including the GATT. The WTO is also based in Geneva.

7. See generally Robert E. Hudec, Enforcing International Trade Law: The Evolution of the Modern GATT Legal System (1993) (presenting a history and analysis of GATT jurisprudence). 
It took seven years of multilateral trade negotiations, called the Uruguay Round (1986-93), to replace the institutional GATT with the WTO through agreements dealing not only with the establishment and organization of the WTO, but also with a diverse range of subjects such as (in addition to the contractual GATT covering trade in goods) trade in services, trade in agricultural products, removal of barriers to trade in textiles, trade aspects of intellectual property, and (perhaps most fundamentally) rules for resolving trade disputes. The volume and scope of trade cases handled by the WTO under those rules since 1995 has been phenomenal, signifying the emergence of the WTO not only as a forum for developing trade policy, but also as the world's most effective international institution for the resolution of disputes between nations.

It would be quite understandable if the NGOs viewed the disputeresolution powers of the WTO in the area of trade as disproportionate to the overall availability of multilateral resources for handling nontrade disputes, particularly environmental disputes. In non-trade areas, there are no counterparts comparable in effectiveness to the WTO. Without question, when viewed from the perspective of, for example, multilateral institutional resources currently available for protecting the environment, the WTO is disproportionately endowed. The multilateral means available to handle trade disputes exceeds by far anything now available in non-trade areas.

Relative excess does not necessarily translate into absolute excess, however, nor into evidence that the WTO has abused its powers. In absolute terms, the WTO is strikingly without power. Its budget and staff are inadequate. ${ }^{8}$ It exists at the sufferance of its member countries (currently 144). Its powerful members, particularly the United States and the European Union, regularly subject the WTO to great pressure. (Witness the U.S. refusal even to attend WTO meetings on U.S. trade sanctions against Cuba or the European Union refusal to acknowledge scientific evidence relating to genetically modified organisms.) The developing nations tend to be of the view that their interests involving, for example, labor mobility are badly served by the WTO, and have been known to adopt inflexible positions, particularly in the area of trade and the environment, where the relevant WTO committee finds itself in prolonged deadlock. The reluctance of devel-

8. See WTO Ready to Accept Private Sector Contributions to Aid Poorer Members, 18 Int'l Trade Rep. (BNA), No. 19, at 739 (May 10, 2001). 
oping countries to adopt environmental policies that would modify their trade policies goes a long way to explaining the reluctance of the U.S. State Department to undertake negotiations with the four Asian countries over sea turtles, as discussed above.

As regards the environment, the WTO has evidenced considerable sensitivity to concerns raised by NGOs, and has increasingly taken those concerns into account. Here, again, the shrimp/sea turtles case provides a useful example. Not only did the environmental arguments prevail, but a careful (or even a quick) reading of what the WTO said as the case progressed also made it quite clear that, to the extent the WTO was in a position to reveal its own wishes in the matter, it sought an outcome consonant with the views of the NGOs. ${ }^{9}$

Whether it smacks of mere opportunism or rises to the level of pragmatism, one can say that the NGOs might be well advised to make friends where they find them. The WTO is no enemy of environmental causes (which are not otherwise lacking in enemies), and, in the long run, demonizing the WTO may have the effect of calling into question not so much its work and mandate as the judgment of the demonizers. In any event, that work and that mandate, directed toward the removal of protectionist barriers to trade, have their own inherent justification: protectionist barriers to trade are harmful to consumers, are destructive of cross-border co-operation, and encourage backward-looking policies grounded in the exclusionary and isolationist practices of trading blocs and imperial mercantilism. In short, putting an end to the work and mandate of the WTO would imply the creation of a world that, all too predictably, would be hostile to a broad spectrum of international causes, not least of all, multilateral environmentalism.

A more productive approach would be to study how the relative success of the WTO has been attained, and to consider whether it is susceptible of emulation in the area of multilateral environmentalism. This is no quick-fix approach, however, for the building of the WTO was an enterprise decades in the making. It required dedicated hard work, patient attention to the diplomatic accommodation of conflicting interests, the case-by-case development and mastery of a substantial

9. See WTO Report of the Appellate Body, United States-Import Prohibition of Certain Shrimp and Shrimp Products, Report of the Appellate Body, AB-1998-4, WT/ DS58/AB/R at para. 185 (Oct. 12, 1998) (stating that "clearly" WTO members "can and should" act to protect the environment and, in this connection, "adopt effective measures to protect endangered species, such as sea turtles."). 
body of jurisprudence, and the skill (and, no doubt, the luck) needed to survive one crisis after another. To learn just how difficult it was to build the WTO requires, at a minimum, a reading of the history of the Uruguay Round of trade negotiations, of the subsequent political maneuvering required to bring about the ratification of the agreements that had been negotiated, and of the follow-up negotiations of such fraught matters as the admission of China (and, simultaneously, of Taiwan) to the WTO. ${ }^{10}$

It would be foolish to suggest that the shifting congeries of political forces that led to today's WTO could, or even should, be replicated to implement the programs of the NGOs. Indeed, in advocating a multilateral approach to protecting the environment, one would hardly wish upon the environmentalists the acute crises and the complex and difficult rounds of negotiations that had to be surmounted in order to achieve a significant level of international trade unfettered by the protectionism of the past. It is hardly self-evident; moreover, how one would go about mustering the political support required to attain the goals of the NGOs (or, for that matter, required to ensure the future vigor of the WTO). Even so, it seems reasonable to suggest that a successful approach to the politics of multilateral environmentalism requires, at a minimum, that the NGOs be conscious of the need to develop their political skills, strategies, and resources, and to adapt them to shifting circumstances over time.

It is in this political context that, like it or not, the environmentalists must analyze the dynamics of multilateralism. They can, of course, adopt a purist policy of opposing globalization in all its forms including multilateral environmentalism. Such a policy of reaction would seem to imply the futile objective of trying to repeal objective global facts, and would hardly win favor with people who take a more balanced approach to weighing the benefits and drawbacks inherent in various aspects of globalization.

A legitimate question would seem to be, what are the alternatives to a multilateral approach to protecting the environment? Essentially, the alternatives come down to permitting each country to pursue its own policies in its own way except to the extent those countries chose to co-ordinate particular policies in particular areas. This would seem to leave the protection of the global environment to the vagaries of

10. See generally Andreas F. Lowenfeld, International Economic Law (2002) (a recent comprehensive treatise in this field). 
national interests from time to time and the fortuities of ad hoc coordination. A multilateral approach implies a sustained effort at reaching global agreements and implementing them through global institutions. Obviously, the advisability of attempting a multilateral approach will turn on the content of the agreements that can be reached, and the quality and vigor of the institutions created to enforce them. ${ }^{11}$

For the time being, negotiating multilateral agreements on various aspects of the environment is notoriously difficult, and the multilateral institutions needed to enforce those agreements are notable for their weakness or, even, their non-existence. Perhaps NGO disgruntlement is centered on the WTO because no companion multilateral institutions exist to deal effectively with non-trade questions involving, for example, labor rights and the environment. The singularity of the WTO makes it unusually if not uniquely visible. Its rulings on the trade aspects of environmental questions may be the most significant multilateral rulings to be issued on those questions simply because no means exist to provide complementary rulings of comparable vitality. In sum, the cure for NGO malaise may be not the disappearance of the WTO but the arrival on the scene of additional institutional players representing a broader effort to achieve multilateralism, and making possible a more comprehensive approach to interconnected global problems.

\section{The Prospects for Institutional Regeneration}

It took the global trauma of World War II to create, in its aftermath, a generation of multilateral institutions, notably, the United Nations, the International Monetary Fund, the International Bank for Reconstruction and Development, and the GATT (which, as mentioned above, was supposed to be, acted as, and eventually was institutionally replaced by, a global trade organization). They were established at about the same time and carried forward by a common wave of political response to the perceived major needs of the time for global co-operation. It may be, sad to say, that only another global trauma can provide multilateral institutional regeneration of comparable dimensions, in which case creation of the multilateral institution called for to handle environmental matters may have to await the polit-

11. For a textbook description of international environmental law as it has evolved in recent years, see Barry E. Carter \& Phillip R. Trimble, International Law 10691144 (3d ed. 1999). 
ics of recreation following global disaster. This train of thought is not encouraging, and will not be pursued.

The institutional regeneration needed to protect the global environment must have as its principal inspiration not concerns over the WTO, but concerns over the environment. Whether or not the (or a) WTO existed, these environmental concerns would provide the rationale for creating an effective multilateral institution with jurisdiction over environmental matters. At present, the text of the GATT contains no environmental provision as such, and has only two clauses that might be labeled as environmental in outlook. Drafted over fifty years ago, they are patently inadequate for dealing with today's environmental problems. ${ }^{12}$ Moreover, the WTO has not been given a mandate to deal with environmental problems-a jurisdictional limitation which would seem to be altogether appropriate (and which also suggests the inappropriateness of some of the criticisms leveled at the WTO by environmental NGOs).

The WTO is relevant not as a compelling reason for the creation of a multilateral environmental institution, but as an existing piece in a potential renascence in the arena of multilateral institutions. ${ }^{13}$ Such a renascence might do more than meet perceived needs for an environmental body with global authority. It might give rise to such a body as a consequence of, and in the context of, a broad-based institutional approach to multilateralism that would provide public support and political regeneration for, among others, the WTO, the financial multilaterals, ${ }^{14}$ the World Health Organization, the International Labor Organization, and the United Nations itself.

12. Two of the ten General Exceptions set out in Article XX of the GATT are paragraphs (b) and (g) thereof which, subject to a proviso forbidding measures that discriminate between countries, respectively permit a country to adopt and enforce measures "necessary to protect human, animal or plant life or health" and measures "relating to the conservation of exhaustible natural resources ...." General Exceptions, GATT B.I.S.D. at 48-50 (1952).

13. In this connection, there seems to be a current vogue for non-legal texts providing views on multilateral institutions. E.g., George Soros, George Soros on Globalization (2002) (existing multilateral institutions, including not only financial multilaterals and the WTO, but also the World Health Organization and the International Labor Organization, should be strengthened); Paul Blustein, The Chastening: Inside the Crisis that Rocked the Global Financial System and Humbled the IMF (2001) (a critical journalistic look at the International Monetary Fund).

14. These might include not only the International Monetary Fund and the institutions often referred to as the World Bank, but also regional institutions such as the 
Were such a regeneration to occur, it seems likely that the WTO, viewed both on a stand-alone basis and as part of some new global architecture, would be found to have merit. Its institutional hardiness during difficult times, its creativity in resolving disputes, its effective blending of various economic, regional and political interests, might then stand up quite well under critical examination. Perhaps it is not too much to suggest the possibility that, in retrospect, even its handling of environmental questions - its contributions to global environmental jurisprudence - may come to be seen as constructive, coherent and useful once a newly created multilateral environmental institution begins to develop its own jurisprudence in the future.

European Bank for Reconstruction and Development, and the Asian Development Bank. 
